\title{
BIODEGRADASI ZAT WARNA REMAZOL BLACK B SECARA AEROBIK- ANAEROBIK DALAM SISTEM BIOFILTRASI VERTIKAL DENGAN MENGGUNAKAN TANAMAN TALAS (Colocasia esculenta)
}

\author{
Febby Hartesa $\mathrm{W}^{1^{*}}$, I Wayan Budiarsa Suyasa ${ }^{1)}$, I Nengah Simpen ${ }^{1)}$ \\ 1) Jurusan Kimia FMIPA Universitas Udayana, Bukit Jimbaran, Bali \\ *Email : hartesafebby@gmail.com
}

\begin{abstract}
The research was conducted to decrease concentration of remazol black b on vertical biosystem of Colocasia esculenta plant with and without addition of activated suspension as variable. The activated suspension was collected from many sources such as sediment of Badung river, Serangan river, Soputan river and dying waste treatment. The aims of this research are: 1) to determine the best activated suspension from seeding sample from some ecosystems, 2) to determine optimal time of vertical biosystem plant to decrease concentration of remazol black b, 3) to know effectivity and capacity of vertical biosystem plant to decrease concentration of remazol black b, TDS and TSS. The results of research show that best activated suspension was provided from sample Serangan river sediment, optimal time to decrease concentration of remazol black b with and without addition of activated suspension is 60 hours and 96 hours. The effectivity system with addition activated suspension to decrease concentration of remazol black b is $97,82 \%$ and capacity is $2,7963 \mathrm{ppm} /$ $\mathrm{m}^{3}$ hours. The effectivity system with addition activated suspension to decrease concentration of TDS is $83,93 \%$ and capacity is $14,44 \mathrm{ppm} / \mathrm{m}^{3}$ hours. The effectivity on system with addition activated suspension to decrease concentration of TSS $89,75 \%$ and capacity is $9,1568 \mathrm{ppm} / \mathrm{m}^{3}$. The effectivity on system without addition activated suspension to decrease concentration of remazol black b is $89,35 \%$ and capacity is 2,5543 $\mathrm{ppm} / \mathrm{m}^{3}$ hours. The effectivity on system without addition activated suspension to decrease concentration of TDS is $65,71 \%$ and capacity is $11,31 \mathrm{ppm} / \mathrm{m}^{3}$ hours. The effectivity on system without addition activated suspension to decrease concentration of TSS is $72,29 \%$ and capacity is $7,3746 \mathrm{ppm} / \mathrm{m}^{3}$ hours.
\end{abstract}

Keywords : activated suspension; biosystem; Colocasia esculenta; remazol black b.

\section{PENDAHULUAN}

Industri tekstil merupakan salah satu industri yang tengah berkembang di Indonesia, hal ini dapat dilihat dari banyaknya keberadaan industri-industri tekstil baik dalam skala besar maupun skala kecil. Keberadaan industri tekstil semakin meningkat seiring dengan meningkatnya kebutuhan akan pakaian. Sebagai salah satu industri yang tengah berkembang di Indonesia saat ini, industri tekstil menghasilkan air limbah berwarna. Perkembangan industri tekstil terus meningkat tidak sebanding dengan pengolahan air limbah yang dihasilkan. Kebanyakan air limbah yang mengandung zat warna dibuang begitu saja ke lingkungan tanpa ada pengolahan terlebih dahulu (Daneshvar et al, 2007).

Zat warna azo paling sering digunakan pada industri tekstil karena dapat terikat kuat pada kain, sehingga tidak mudah luntur dan memberikan warna yang baik. Selain itu, zat warna azo mudah ditemukan dan memiliki variasi warna yang lebih banyak dibandingkan pewarna alami (Pandey et al., 2007). Zat warna azo disintesis untuk tidak mudah rusak oleh perlakuan kimia maupun fotokatalitik, sehingga apabila dibuang ke dalam perairan akan merusak estetika perairan tersebut serta meracuni biota air. Hal ini disebabkan berkurangnya oksigen yang dihasilkan dari proses fotosintesis akibat terhalangnya sinar matahari yang masuk ke dalam badan air (Zee, 2002). Untuk itu, sebelum dibuang ke lingkungan limbah zat berwarna tersebut harus diolah terlebih dahulu untuk menghilangkan atau menurunkan kadar bahan pencemar yang terkandung didalamnya sehingga limbah cair aman untuk dibuang ke badan air atau lingkungan (sesuai dengan baku mutu yang ditetapkan).

Dalam hal penanganan pencemaran limbah yang ditimbulkan dari industri pencelupan tekstil dapat dilakukan pengolahan terhadap air limbah berwarna baik secara kimia, fisika, biologi maupun gabungan dari ketiganya. Pengolahan limbah tekstil secara kimia dan fisika cukup efektif untuk menghilangkan warna, namun memiliki kelemahan yaitu biaya operasional relatif mahal. Pengolahan air limbah yang mengandung berbagai bahan organik dan anorganik haruslah efisien, tidak memerlukan lahan yang luas, ekonomis, serta tidak menimbulkan polutan baru yang dapat mencemari lingkungan. Suatu sistem pengolahan limbah yang efektif harus mampu menurunkan kadar bahan-bahan pencemar dalam air limbah hingga memenuhi ketentuan yang berlaku. Pengolahan secara biologis adalah 
pengolahan limbah yang efektif, murah dan ramah lingkungan. Pengolahan air limbah secara biologis terutama diarahkan untuk mengolah bahan organik terlarut dari air limbah, dilakukan dengan cara anaerob, aerob atau dengan gabungan cara anaerobaerob (Budiyono dan Sunarso, 2007).

Biofiltrasi merupakan salah satu proses pengolahan limbah secara biologis yang pada prinsipnya melibatkan mikroba (bakteri pengurai) sebagai media penghancur bahan-bahan pencemar. Proses perombakan zat warna azo oleh bakteri pada dasarnya merupakan reaksi redoks yang dikatalisis oleh enzim. Koenzim nikotinamida adenin dinukleotida $\left(\mathrm{NAD}^{+}\right)$yang dibebaskan pada proses glikolisis glukosa dengan bantuan enzim dehidrogenase berperan sebagai pembawa elektron dan terlibat dalam reaksi enzimatik. Pada kondisi tidak ada oksigen, NADH mengalami reaksi oksidasi menghasilkan $\mathrm{NAD}^{+}$sedangkan zat warna azo mengalami reaksi reduksi menghasilkan aminaamina aromatik yang bersesuaian. Putusnya ikatan azo pada zat warna azo menyebabkan warna menjadi hilang. Pada kondisi anaerob degradasi zat warna tekstil menggunakan bakteri lebih cepat dibandingkan dengan kondisi aerob, namun kelemahannya yaitu menghasilkan amina aromatik yang bersifat lebih toksik dibandingkan dengan zat warna azo itu sendiri. Hasil uji toksisitas menunjukkan degradasi limbah tekstil pada kondisi anaerob lebih toksik dibandingkan dengan limbah awal (Sastrawidana, 2012). Untuk itu perlu dilanjutkan pengolahan pada tahap anaerob untuk mengubah senyawa organik menjadi $\mathrm{CO}_{2}, \mathrm{H}_{2} \mathrm{O}, \mathrm{NH}_{3}$.

Hasil penelitian Purnamawati (2015) menyatakan bahwa, pengolahan limbah rhodamin $b$ dalam biofiltrasi sistem tanaman mampu menurunkan kadar rhodamin $b$, TDS dan TSS berturut-turut sebesar 51,07\%, 47,60\%, 50,44\%. Wibowo dan Komarawidjaja (2012) dalam penelitiannya menggunakan tanaman talas mampu mereduksi kandungan bahan pencemar dalam air terutama Nitrogen $(\mathrm{N})$, karbon $(\mathrm{C})$, dan fosfat $\left(\mathrm{PO}_{4}{ }^{3}\right.$. ), sehingga talas dapat dimanfaatkan untuk mereduksi suatu pencemar organik.Tanaman merupakan makhluk hidup yang memerlukan unsur-unsur hara yang esensial bagi pertumbuhannya. Tanaman mampu menyerap zatzat yang terkandung dalam air limbah, seperti nitrit, nitrat, amonium, dan sulfur dalam bentuk sulfat (Lakitan, 2007). Oleh karena itu, pada penelitian ini dilakukan penurunan kadar zat warna remazol black $b$ secara aerobik-anaerobik dalam sistem biofiltrasi vertikal dengan menggunakan tanaman talas. Teknik biofilter memiliki beberapa keunggulan diantaranya pengoperasiannya mudah, lumpur yang dihasilkan sedikit, tingkat efisiensinya tinggi, serta dapat menghilangkan padatan tersuspensi dengan baik. Pengolahan ini diawali dengan cara melakukan pembibitan untuk memilih suspensi aktif terbaik yang nantinya akan ditambahkan kedalam sistem pengolahan. Adapun sumber suspensi aktif yang digunakan diambil dari beberapa tempat berbeda yaitu, sedimen Sungai Badung, sedimen Sungai yang berlokasi di Pulau Serangan, sedimen Sungai Soputan dan lumpur hasil pengolahan limbah tekstil. Parameter pendukung dalam penelitian ini adalah TSS dan TSS, pemilihan kedua parameter tersebut adalah untuk mengetahui kemampuan sistem biofiltrasi vertikal tanaman dalam mengurangi padatan total serta benda padat terlarut yang terkandung setelah pengolahan. Sistem pengolahan ini diharapkan dapat melakukan proses pengolahan dalam menurunkan kadar remazol black $b$, serta penyisihan bahan organik terlarut dan tersuspensi dalam limbah zat warna remazol black $b$.

\section{METODOLOGI}

\subsection{Tempat dan Waktu Penelitian}

Penelitian dilakukan di Laboratorium Penelitian Jurusan Kimia FMIPA Unud Laboratorium Bersama FMIPA Unud di Kampus Bukit Jimbaran. Waktu penelitian selama 3 bulan dari bulan maret- mei.

\subsection{Alat dan Bahan Penelitian}

Bahan-bahan yang digunakan dalam penelitian ini adalah: zat warma tekstil buatan (remazol black $b$ teknis), tanaman (Colocasia esculenta), sampel tanah dari beberapa ekosistem, glukosa, $\mathrm{K}_{2} \mathrm{HPO}_{4}$, $\mathrm{KH}_{2} \mathrm{PO}_{4},\left(\mathrm{NH}_{4}\right)_{2}\left[\mathrm{Fe}\left(\mathrm{SO}_{4}\right)_{2}\right] .6 \mathrm{H}_{2} \mathrm{O}, \mathrm{MgSO}_{4}, \mathrm{FeSO}_{4}$, $\mathrm{K}_{2} \mathrm{Cr}_{2} \mathrm{O}_{4}$ berasal dari Merck, ekstrak ragi dari Haan, Aqua DM dari Brataco Chemika. Alat-alat yang diperluan dalam penelitian ini antara lain : aluminium foil, kain kasa, kertas saring Whatman 42 dari Ajax Chemical, erlenmeyer Pyrex, gelas ukur Approx, bola hisap, pipet tetes, pipet volume dari Socorex, tanur, gelas beker Pyrex, aerator 6 buah, spektrofotometer UV-VIS 1800 Shimadzu, oven dari Memmert, desikator, labu ukur Approx, kulkas, autoklaf All American 75x, timbangan Ohaus Galaxy 400, neraca analitik Pioneer.

Unit pengolahan biofiltrasi tanaman vertikal dibuat dari pipa paralon berukuran diameter $12 \mathrm{~cm}$ dan panjang $90 \mathrm{~cm}$. Pipa diposisikan dalam keadaan vertikal, bagian dalam pipa diisi dengan batu koral setinggi $60 \mathrm{~cm}$ dari dasar permukaan pipa dan diatasnya ditambahkan pasir setinggi $22 \mathrm{~cm}$ sebagai media tumbuhnya tanaman. Di dalam pipa paralon tersebut ditanam 1 buah Colocasia esculenta yang memiliki daun 3 lembar dengan posisi tegak. Pada bagian bawah pipa dibuat kran setinggi $15 \mathrm{~cm}$ dari dasar pemukaan pipa untuk mengalirkan efluen air limbah yang sudah memasuki keadaan aerobik anaerobik. Sistem biofilter tanaman vertikal 


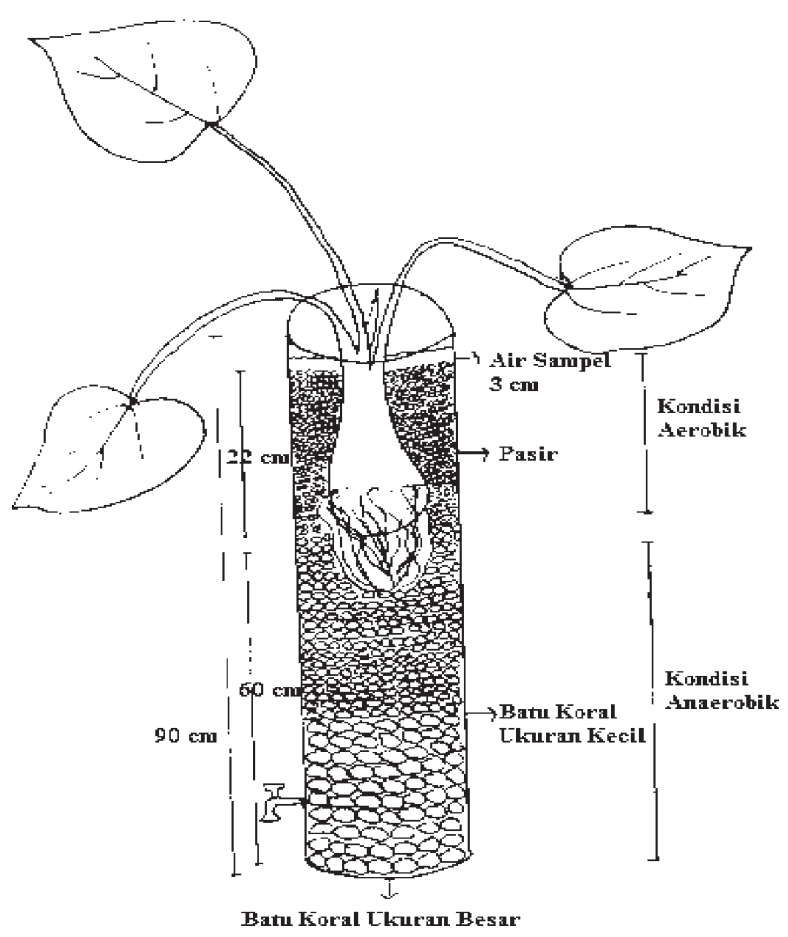

Gambar 1. Sistem Biofilter Vertikal Tanaman

\subsection{Prosedur Penelitian}

\subsubsection{Sampling Sedimen}

Sedimen lumpur tercemar diambil menggunakan sekop dengan kedalaman $10-20 \mathrm{~cm}$ dari permukaan dasar sebanyak \pm 100 gram. Masingmasing lumpur diambil dengan menentukan tiga titik sesuai arah mata angin yaitu pada bagian utara, selatan dan barat sungai maupun bak pembuangan limbah dengan asumsi dapat mewakili satu tempat, lalu diletakkan sementara pada kantong plastik klip dan disimpan pada cooler box.

\subsubsection{Pembibitan (Seeding)}

Pembibitan suspensi aktif dilakukan dengan mengambil 0,5 gram sedimen lumpur dari masingmasing ekosistem kemudian tiap sedimen dimasukan kedalam gelas beaker yang berisi media cair sebanyak $500 \mathrm{~mL}$. Media pada masing-masing gelas beaker diaerasi dengan menggunakan aerator yang diberi selang yang diletakan didasar gelas beaker. Gelas beaker ditutup dengan kain kasa dan diikat dengan karet lalu didiamkan selama 48 jam. Pada jam ke 6 , 12, 28 dan 48 aerator dimatikan dan didiamkan beberapa saat selama 10-15 menit untuk mengetahui perkembangan isolat bakteri dengan mengukur nilai VSS (Volatile Suspended Solid).

\subsubsection{Pengolahan limbah sistem biofilter vertikal tanaman secara aerobik - anaerobik}

Dua buah paralon disiapkan sebagai sistem biofiltrasi vertikal tanaman. Pipa pertama dan kedua diisi media koral, pasir serta tanaman talas yang tumbuh sehat dan baik. Pada pipa pertama dimasukkan sejumlah air limbah yang mengandung remazol black b konsentrasi 46,517 ppm sampai sistem biofilter basah oleh air limbah. Pada pipa kedua, sebelum dialirkan zat warna remazol black $b$ konsentrasi 46,517 ppm, ditambahkan terlebih dahulu sumber bibit terbaik kemudian sumber bibit diadaptasikan selama 12 jam pada sistem biofilter. Setelah itu sumber bibit dialirkan keluar melalui kran. Sejumlah air limbah remazol black $b$ sebanyak 3,6 L dimasukkan kedalam sistem biofilter hingga sistem basah oleh air limbah. Proses pengolahan remazol black $b$ pada sistem biofiltrasi vertikal dilakukan selama 96 jam. Setiap selang waktu 4 jam pengolahan, dilakukan pengambilan sampel air untuk analisis penurunan konsentrasi remazol black $b$ dengan memplot grafik antara waktu pengolahan dan penurunan konsentrasi. Kurva yang mengalami penurunan konstan dianggap sebagai kadar akhir serta dapat ditentukan waktu optimal terhadap penurunan kadar remazol black $b$ berdasarkan baku mutu air limbah domestik. Pengamatan sampel air juga dilakukan dengan mengukur kadar Total Dissolved Solid (TDS), dan kadar Total Suspended Solid (TSS). Dari pengukuran kadar remazol black $b$ dilakukan perhitungan mengenai tingkat efektivitas dan kapasitas sistem biofiltrasi vertikal tanaman dalam menurunkan kadar remazol black $b$, TDS dan TSS sesuai baku mutu yang ditetapkan.

\section{HASIL DAN PEMBAHASAN}

\subsection{Hasil Suspensi Aktif Terbaik dengan Pembibitan Sampel Sedimen Sungai dari Beberapa Ekosistem}

Berdasarkan hasil nilai VSS yang diperoleh pada masing-masing suspensi aktif pada proses pembibitan, menunjukan bahwa suspensi aktif II dengan komposisi lumpur yang berasal dari sedimen Sungai Serangan merupakan suspensi aktif terbaik. Pemilihan suspensi aktif terbaik berdasarkan waktu tercepat dalam memperoleh nilai VSS tertinggi, dimana pada waktu optimal pembibitan 12 jam nilai VSS tertinggi ditunjukan pada suspensi aktif yang berasal dari sedimen lumpur Sungai Serangan.

Jika dilihat dari kurva pertumbuhan nilai VSS yang diperoleh suspensi aktif II pada jam ke 6 terjadi peningkatan yang sangat cepat terhadap pertumbuhan biomassa. Hal ini kemungkinan disebabkan jumlah dan aktivitas mikroorganisme yang tinggi sehingga selama pembibitan terjadi pertumbuhan yang cepat. Pada jam ke 12 terjadi fase stasioner dimana tidak terjadi pengingkatan maupun penurunan terhadap pertumbuhan biomassa. Hal ini terjadi karena nutrien yang dibutuhkan oleh bakteri telah berkurang. Pada jam ke 28 dan 48 terjadi fase kematian akibat nutrisi dalam media cair telah habis sehingga terjadi penurunan kurva nilai VSS. 


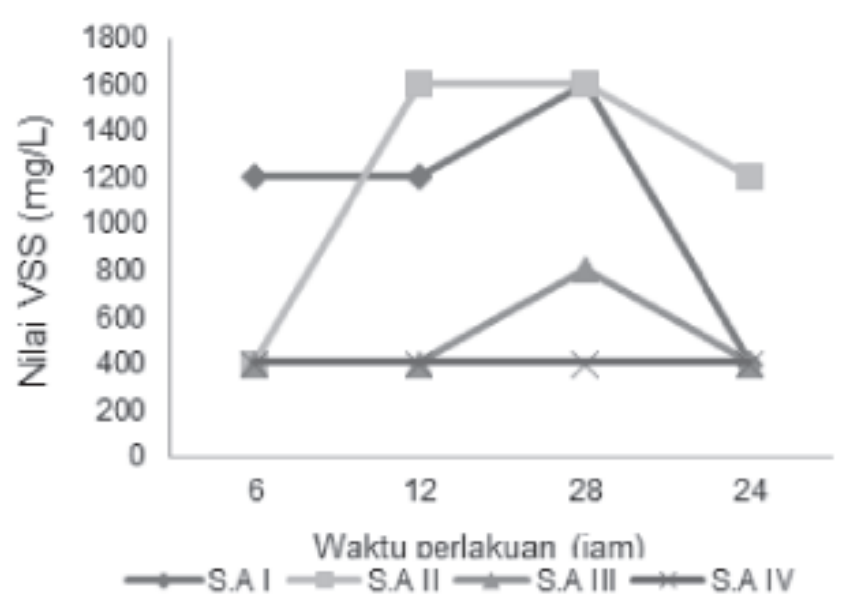

Gambar 2. Kurva Pertumbuhan Biomassa Suspensi Aktif Keterangan:

- Suspensi Aktif I = sedimen Sungai Badung

- Suspensi Aktif II = sedimen Sungai Serangan

- Suspensi Aktif III = sedimen Sungai Soputan

- Suspensi Aktif IV = lumpur limbah pencelupan tekstil

Kecepatan kurva kematian lebih lambat dibandingkan kurva penurunan biomassa.

Dibandingkan ketiga suspensi aktif lainnya, sedimen lumpur Sungai Serangan memiliki waktu tercepat, yakni 12 jam untuk mencapai nilai VSS tertinggi sebesar $1600 \mathrm{mg} / \mathrm{L}$. Kondisi lingkungan disekitar tempat pengambilan sampel Sungai Serangan merupakan perairan tercemar yang mengandung limbah domestik dengan kadar organik yang tinggi dimana apabila suatu perairan tercemar mengandung bahan organik tinggi akan tercipta suasana yang sesuai bagi mikroba untuk menggunakan bahan organik tersebut dalam proses metabolismenya. Aktivitas mikroba yang semakin tinggi dalam menguraikan bahan organik maka semakin tinggi pula biomassa yang dihasilkan (Mukono, 2000).

\subsection{Waktu Optimal Perlakuan Biosistem Vertikal Tanaman Terhadap Perubahan Kadar Remazol Black B}

Pada penelitian ditentukan waktu optimal pengolahan dengan membandingkan hasil penurunan kadar remazol black $b$ setiap selang 4 jam dengan baku mutu air limbah domestik yang sudah ditetapkan. Adapum kurva pengukuran kadar remazol black b selama 96 jam disajikan pada Gambar 3 dan Gambar 4.

Pada sistem pengolahan dengan perlakuan tanpa penambahan suspensi aktif terlihat bahwa kurva kadar remazol black $b$ mengalami laju penurunan yang pesat diawal perlakuan hingga jam ke 12 , kemudian pada rentang waktu pengolahan jam ke 12 hingga jam ke 36 laju penurunan masih terlihat pesat. Hal ini dikarenakan kebutuhan nutrien bagi mikroorganisme masih mencukupi untuk berkembang biak serta melaksanakan aktivitas penguraian. Ketika memasuki waktu pengolahan jam

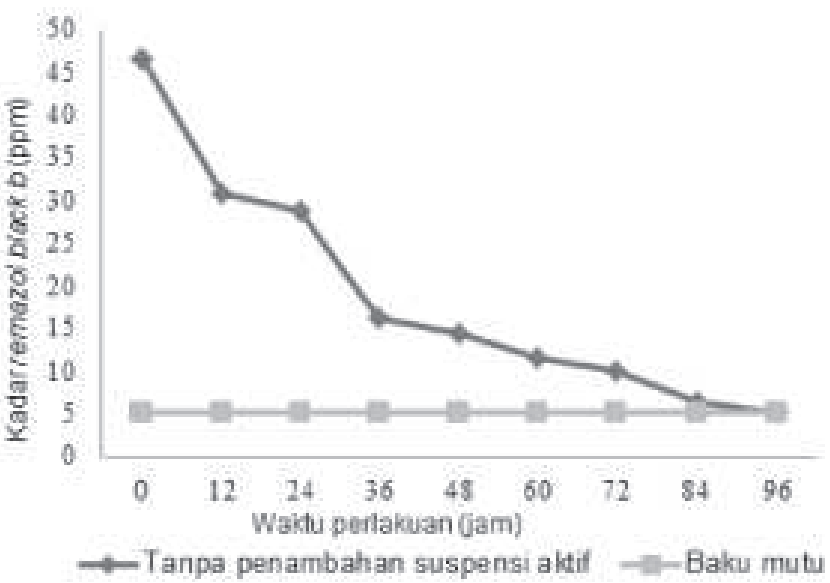

Gambar 3. Tanpa Penambahan Suspensi Aktif

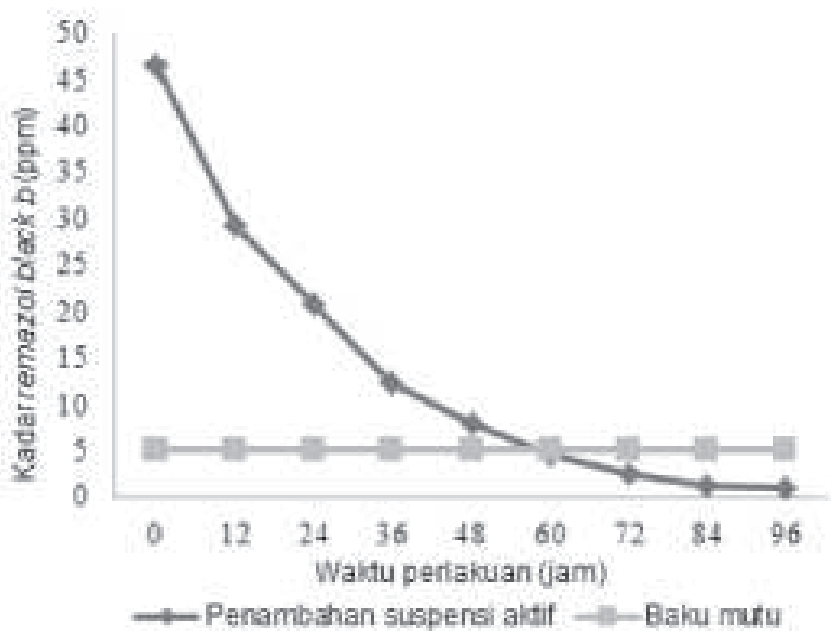

Gambar 4. Penambahan Suspensi Aktif

ke 36, terlihat laju kurva penurunan kadar remazol black $b$ mulai melambat hingga memasuki waktu pengolahan jam ke 84. Hal ini terjadi karena kondisi mikroorganisme mulai kehabisan sumber nutrien dan tidak ada tambahan nutrien lagi sehingga mikroorganisme tidak bisa melakukan pertumbuhan dan aktivitas penguraian akan semakin menurun karena mikroorganisme sudah berada dalam kondisi jenuh yang disebut dengan keadaan stationary phase. Jika waktu pengolahan dilanjutkan diatas 96 jam maka kemungkinan besar grafik yang dihasilkan akan cenderung stabil yang menunjukkan bahwa mikroorganisme sudah tidak mampu lagi melakukan aktivitasnya dalam menguraikan remazol black $b$ akibat kekurangan nutrien sehingga lama kelamaan akan mencapai endogenous phase, yaitu suatu kondisi dimana mikroorganisme mengalami kematian dengan laju kematian tinggi dan terjadi cell lysis. Selain itu, pada waktu perlakuan ke 96 jam kadar remazol black $b$ telah berada dibawah baku mutu air limbah domestik dengan konsentrasi sebesar 4,9530 ppm, sehingga waktu optimal yang diperlukan untuk menurunkan kadar remazol black $b$ hingga berada dibawah baku mutu adalah 96 jam. 
Berdasarkan Gambar 4. pada sistem pengolahan dengan penambahan suspensi aktif terlihat bahwa laju penurunan kadar remazol black $b$ terjadi dengan pesat diawal waktu pengolahan hingga jam ke 36 . Hal ini kemungkinan disebabkan adanya sumber nutrien yang mencukupi pada selang waktu pengolahan tersebut sehingga menyebabkan aktivitas mikroorganisme untuk menguraikan remazol black $b$ akan semakin pesat. Kurva laju penurunan kadar remazol black $b$ mulai mengalami perlambatan pada jam ke 48. Hal ini menunjukan bahwa mikroorganisme sudah memasuki stationary phase. Pada jam ke 84 penurunan kurva kadar remazol black $b$ mulai stabil, dimana dalam keadaan ini terjadi endogenous phase. Pada pengolahan penambahan suspensi aktif kurva penurunan kadar zat warna lebih cepat stabil dibandingkan dengan sistem pengolahan tanpa penambahan suspensi aktif. Hal ini dikarenakan pada sistem dengan penambahan suspensi aktif mendapat tambahan mikroorganisme dari luar sehingga jumlah mikroorganisme yang ada lebih banyak dalam menggunakan sumber nutiren sebagai makanan dalam proses menguraikan zat warna. Waktu optimal yang diperoleh dalam menurunkan kadar remazol black b sesuai baku mutu pada sistem pengolahan dengan penambahan suspensi aktif adalah 60 jam. Perbedaan pencapaian waktu optimal ini disebabkan karena adanya penambahan mikroorganisme dari luar pada pipa II dengan perlakuan penambahan suspensi aktif sehingga jumlah mikroorganisme semakin banyak, maka kemampuan aktivitas mikroorganisme dalam memutuskan ikatan azo semakin meningkat dan mampu menurunkan kadar zat warna dibawah baku mutu yang ditetapkan sebelum mikoorganisme berada dalam kondisi stationary phase.

\subsection{Efektifitas dan Kapasitas Pengolahan Biosistem Vertikal Tanaman dalam Menurunkan Kadar Remazol Black B, TDS dan TSS}

Efektivitas dari pengolahan limbah remazol black $b$ secara biosistem vertikal tanaman dengan dan tanpa penambahan suspensi aktif dalam menurunkan kadar remazol black $b$, nilai TDS dan TSS berturut-turut disajikan dalam Gambar 5, Tabel 1, dan Tabel 2.

Pada biosistem vertikal tanaman dengan penambahan suspensi aktif dengan waktu optimal selama 60 jam, diperoleh nilai efektivitas sebesar

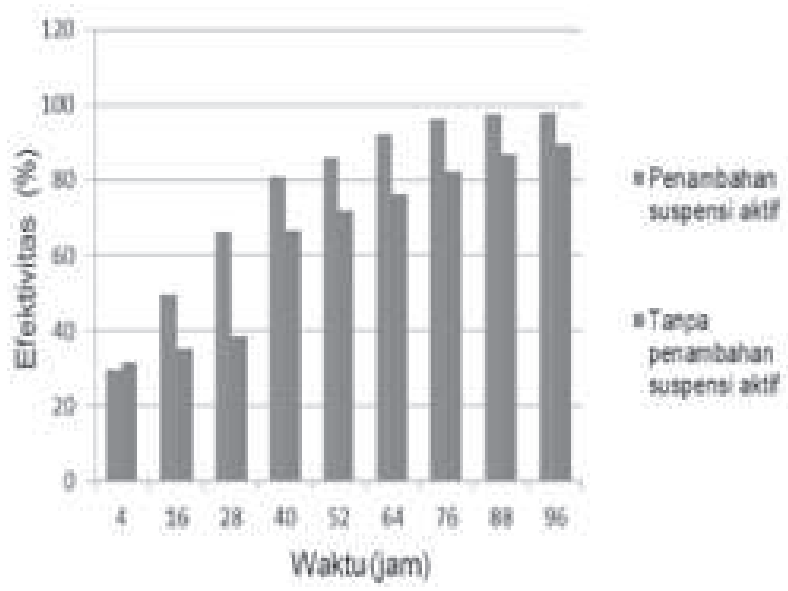

Gambar 5. Grafik Efektivitas (\%) Penurunan Kadar Remazol Black B pada Pengolahan Biosistem Tanaman

Tabel 1. Efektivitas (\%) Penurunan Nilai TDS pada Pengolahan Biosistem VertikalTanaman

\begin{tabular}{ccccc}
\hline $\begin{array}{c}\text { Waktu } \\
\text { perlakuan (jam) }\end{array}$ & $\begin{array}{c}\text { TDS rata-rata dengan } \\
\text { penambahan suspensi } \\
\text { aktif(mg/L) }\end{array}$ & $\begin{array}{c}\text { Efektivitas (\%) } \\
\text { penambahan } \\
\text { suspensi aktif }\end{array}$ & $\begin{array}{c}\text { TDS rata-rata } \\
\text { penambahan mikroorga- } \\
\text { nisme (mg/L) }\end{array}$ & $\begin{array}{c}\text { Efektivitas (\%) } \\
\text { tanpa penambahan } \\
\text { suspensi aktif }\end{array}$ \\
\hline 0 & 280 & 0 & 280 & 0 \\
24 & 241 & 13,93 & 256 & 8,57 \\
48 & 196 & 30 & 208 & 25,71 \\
96 & 112 & 60 & 174 & 37,85 \\
\end{tabular}

Keterangan: Nilai TDS maksimum yang dibolehkan berdasarkan Baku Mutu Air Limbah Industri Tekstil ( Peraturan Menteri Lingkungan Hidup Republik Indonesia Nomor 5 Tahun 2014) : $50 \mathrm{mg} / \mathrm{L}$.

Tabel 2. Efektivitas (\%) Penurunan Nilai TSS pada Pengolahan Biosistem Vertikal Tanaman

\begin{tabular}{ccccc}
\hline $\begin{array}{c}\text { Waktu } \\
\text { perlakuan (jam) }\end{array}$ & $\begin{array}{c}\text { TSS rata-rata dengan } \\
\text { penambahan suspensi } \\
\text { aktif(mg/L) }\end{array}$ & $\begin{array}{c}\text { Efektivitas (\%) } \\
\text { penambahan } \\
\text { suspensi aktif }\end{array}$ & $\begin{array}{c}\text { TSS rata-rata dengan } \\
\text { penambahan miroor- } \\
\text { ganisme (mg/L) }\end{array}$ & $\begin{array}{c}\text { Efektivitas (\%) } \\
\text { tanpa penambahan } \\
\text { suspensi aktif }\end{array}$ \\
\hline 0 & 166 & 0 & 166 & 0 \\
24 & 132 & 20,48 & 156 & 6,02 \\
48 & 98 & 40,96 & 117 & 29,52 \\
92 & 66 & 60,24 & 84 & 49,39 \\
\\
\hline 6 & 17 & 89,75 & 46 & 72,29 \\
\hline
\end{tabular}

Keterangan : Nilai TSS maksimum yang dibolehkan berdasarkan Baku Mutu Air Limbah Industri Tekstil ( Peraturan Menteri Lingkungan Hidup Republik Indonesia Nomor 5 Tahun 2014): $50 \mathrm{mg} / \mathrm{L}$ 
$90,36 \%$, sedangkan biosistem vertikal tanpa penambahan suspensi aktif dengan waktu optimal selama 96 jam, diperoleh nilai efektivitas sebesar 89,35\%. Untuk nilai TDS, efektivitas ditentukan berdasarkan penurunan terbaik karena nilai TDS diawal perlakuan untuk sistem baik dengan dan tanpa penambahan suspensi aktif sudah berada dibawah baku mutu air limbah domestik. Untuk biosistem vertikal tanaman dengan penambahan suspensi aktif pemurunan nilai TDS terbaik terjadi pada waktu perlakuan 96 jam dengan persentase efektivitas sebesar $83,93 \%$, sedangkan pada biosistem vertikal tanaman tanpa penambahan suspensi aktif penurunan nilai TDS terbaik terjadi pada waktu perlakuan 96 jam dengan persentase efektivitas sebesar $65,71 \%$. Untuk nilai TSS, nilai efektivitas pada biosistem dengan penambahan suspensi aktif dengan penurunan 89,75\% selama 96 jam, sedangkan untuk biosistem tanpa penambahan suspensi aktif turun sebesar $72,29 \%$ dan nilai TSS yang diperoleh untuk perlakuan dengan dan tanpa penambahan suspensi aktif sudah berada dibawah baku mutu yang ditentukan masing - masing sebesar $17 \mathrm{mg} / \mathrm{L}$ dan $46 \mathrm{mg} / \mathrm{L}$. Pada pengolahan biosistem vertikal tanaman dengan penambahan suspensi aktif nilai efektivitas TDS dan TSS lebih besar dari pada biosistem vertikal tanaman tanpa penambahan suspensi aktif, hal ini terjadi karena adannya peranan mikroorganisme yang ditambahkan dalam mengubah bahan organik seperti senyawa azo menjadi ukuran yang lebih kecil dalam proses degradasi sehingga menyebabkan penurunan kadar TDS dan TSS lebih rendah sehingga nilai efektivitas keduanya lebih besar. Penurunan nilai dari ketiga parameter tersebut menunjukan hasil yang bagus, baik dengan sistem yang terdapat penambahan suspensi aktif maupun tidak karena nilainya sudah berada di bawah baku mutu air limbah domestik. Pengolahan biosistem vertikal tanaman sangat efektif dalam menurunkan nilai parameter TDS, TSS dengan sistem penambahan suspensi aktif serta kadar remazol black $b$ untuk sistem dengan dan tanpa penambahan suspensi aktif karena efektitivitas yang diperoleh berada diatas $80 \%$. Untuk sistem pengolahan tanpa penambahan suspensi aktif terbilang efektif dalam menurunkan nilai parameter TDS dan TSS karena efektivitas yang diperoleh keduanya berkisar antara 50\%-80\%.

Penelitian dengan pengolahan biosistem vertikal tanaman talas dengan penambahan suspensi aktif memiliki nilai efektivitas yang lebih besar dalam menurunkan parameter zat warna, TDS dan TSS dibandingkan penelitian yang dilakukan oleh Sumarni (2012), dengan metode absorben kombinasi karbon aktif dan pasir aktif dalam menurunan kadar zat warna dan nilai TSS, dimana persentase efektivitas yang diperoleh adalah 86,5\% dan 87,9\%.
Berdasarkan efektivitas pengolahan limbah remazol black b maka dapat ditentukan kapasitas dari pipa pengolahan biosistem vertikal tanaman dalam menurunkan kadar remazol black $b$, nilai TDS dan TSS. Dalam menurunkan kadar remazol black $b$ oleh pipa pengolahan biosistem vetikal tanaman talas, diperoleh kapasitas sebesar $2,5543 \mathrm{ppm} / \mathrm{m}^{3} \mathrm{jam}$ untuk pipa pengolahan tanpa penambahan suspensi aktif dan 2,5832 $\mathrm{ppm} / \mathrm{m}^{3}$ jam untuk pipa pengolahan dengan penambahan suspensi aktif. Jadi selama waktu tinggal $96 \mathrm{jam}, 1 \mathrm{~m}^{3}$ pipa pengolahan mampu menurunkan nilai TDS sebanyak $11,31 \mathrm{ppm} / \mathrm{m}^{3} \mathrm{jam}$ tanpa penambahan suspensi aktif dan $14,44 \mathrm{ppm} /$ $\mathrm{m}^{3}$ jam dengan penambahan suspensi aktif. Untuk menurunkan nilai TSS, pipa pengolahan mempunyai kapasitas sebesar $7,3746 \mathrm{ppm} / \mathrm{m}^{3} \mathrm{jam}$ tanpa penambahan suspensi aktif dan $9,1568 \mathrm{ppm} / \mathrm{m}^{3} \mathrm{jam}$ untuk sistem dengan penambahan suspensi aktif. Dari data di atas dapat dilihat bahwa biosistem dengan penambahan suspensi aktif memiliki nilai kapasitas pengolahan yang lebih besar dalam menurunan kadar remazol black $b$, nilai TDS dan TSS karena dengan mikroorganisme yang lebih banyak maka senyawa organik yang dapat diuraikan akan semakin banyak pula. Hasi penelitian ini juga didukung oleh Putra (2015), yang menyebutkan bahwa hasil pengolahan biosostem tanaman dengan penambahan suspensi aktif memiliki nilai kapasitas pengolahan yang lebih besar dalam menurunkan kandungan surfaktan, fosfat, dan COD pada air limbah laundri.

\section{SIMPULAN DAN SARAN}

\subsection{Simpulan}

1. Suspensi aktif terbaik diperoleh pada sampel sedimen Sungai Serangan dengan perolehan nilai VSS tertinggi1600 mg/L pada jam ke 12 .

2. Waktu optimal yang diperlukan dalam menurunkan kadar remazol black $b$ hingga berada dibawah baku mutu yang ditentukan untuk pengolahan dengan penambahan suspensi aktif adalah 60 jam sedangkan untuk pengolahan tanpa penambahan suspensi aktif adalah 96 jam.

3. Efektivitas dan kapasitas pada sistem tanpa penambahan suspense aktif untuk penurunan kadar remazol black $b$ adalah 89,35\% dan 2,5543 $\mathrm{ppm} / \mathrm{m}^{3} \mathrm{jam}$. Untuk TDS sebesar $65,71 \%$ dan $11,31 \mathrm{ppm} / \mathrm{m}^{3}$ jam dan $72,29 \%$ dan $7,3746 \mathrm{ppm} /$ $\mathrm{m}^{3}$ jam untuk TSS. Efektivitas dan kapasitas dengan penambahan suspensi aktif untuk penurunan kadar remazol black $b$ adalah 90,36\% dan $2,5832 \mathrm{ppm} / \mathrm{m}^{3} \mathrm{jam}$. Untuk TDS sebesar $83,93 \%$ dan $14,44 \mathrm{ppm} / \mathrm{m}^{3} \mathrm{j}$ am dan $89,75 \%$ dan $9,1568 \mathrm{ppm} / \mathrm{m}^{3} \mathrm{jam}$ untuk TSS. 


\subsection{Saran}

1. Perlu dilakukan penelitian lebih lanjut dengan menggunakan jenis tanaman yang berbeda untuk menurunkan kadar remazol black $b$.

2. Perlu dilakukan penelitian menggunakan zat warna yang langsung berasal dari industri tekstil.

\section{DAFTAR PUSTAKA}

Budiyono, I. N., dan Sunarso, W., 2007, Perkembangan Teknologi Pengolahan Air Limbah Rumah Pemotongan Hewan (RPH), Prosiding Nasional Fundamental dan Aplikasi Teknik Kimia, Institut Teknologi Sepuluh November, Surabaya

Daneshvar, N., Ayazloo, M., Khatae, A.R., and Pourhassan, M., 2007, Biological Decolorization of Dye Solution Containing Malachite Green by Microalgae Cosmarium sp, Bioresource Technology. 98 (6) : 1176- 1182

Lakitan, B, 2007, Dasar-dasar Fisiologi Tumbuhan, PT. Raja Grifando Persada, Jakarta.

Mukono, H.J., 2000, Prinsip Dasar Kesehatan Lingkungan, Airlangga University Press
Pandey, A., Singh, P., Lyengar L., 2007, Bacterial Decolorization and Degradation of Azo Dyes, Journal Int Biodet Biodeg, 59 : 73-84

Purnamawati, K.Y., Suyasa, I.W.B., Mahardika, I.G., 2015, Penurunan Kadar Rhodamin B dalam Air Limbah dengan Biofiltrasi Sistem Tanaman, Ecotrophic: Journal of Environmental Science., $9(2): 46-51$

Putra, S., 2015, Biofilter Saringan Tanaman Pasir Pada Limbah Deterjen dalam Menurunkan Surfaktan, BOD (Biological Oxygen Demand) dan COD (Chemical Oxygen Demand), Skripsi, Universitas Udayana, Bali

Sastrawidana, I D. K., Maryam, S., Sukarta, I. N. 2012. Perombakan Air Limbah Tekstil Menggunakan Jamur Pendegradasi Kayu Jenis Polyporus Sp 56 Teramobil Pada Serbuk Gergaji Kayu. Jurnal Bumi Lestari, 12 (2) : 382 - 389

Sumarni, 2012, Adsorpsi Zat Warna dan Zat Padat Tersuspensi dalam Limbah Cair Batik, Prosiding: Seminar Nasional Aplikasi Sains \& Teknologi (SNAST) Periode III, Yogyakarta, 3 November 2012

Zee, V.D., 2002, Anaerobic Azo Dye Reduction, Thesis, Wageningen University, Netherlands 